\title{
Meningkatkan Kesejahteraan Subjektif Penderita Penyakit Jantung Melalui Pelatihan Kebersyukuran
}

\author{
Ririn Nur Abdiah Bahar dan Moordiningsih \\ Universitas Mercu Buana Yogyakarta
}

\begin{abstract}
Individuals diagnosed with heart disease, especially at young people will cause psychological burden because they have to do long-term treatment, even last a lifetime with various risks that accompany, so that it will reduce subjective well-being for sufferers. The hypothesis of this study is subjective well-being of people with heart disease increases after receiving Gratitude Training. This study uses one group pretest-posttest with follow-up design. The measurement of subjective well-being is done by using SWLS and PANAS in Indonesian version. Gratitude training is given to individuals diagnosed with heart disease at productive age, 20-45 years $(n=5)$. Subjects attended the Gratitude Training 2 times online meetings. The analysis used in this study, the Friedman Test which showed significant results $\left(\chi_{r}{ }^{2}=8.4\right.$; $p$ <0.05). These results indicate that the Gratitude Training in this study was proven to improve subjective well-being in people with heart disease.
\end{abstract}

Keywords: Gratitude Training; People with heart disease: Subjective Well-Being

\begin{abstract}
Abstrak
Individu yang terdiagnosa penyakit jantung, terutama pada usia muda akan menimbulkan beban psikologis karena harus melakukan pengobatan jangka panjang, bahkan berlangsung seumur hidup dengan berbagai risiko yang menyertai, sehingga akan menurunkan kesejahteraan subjektif bagi penderita. Hipotesis dari penelitian ini yaitu kesejahteraan subjektif penderita penyakit jantung meningkat setelah mendapatkan Pelatihan Kebersyukuran. Penelitian ini menggunakan desain one group pretest-posttest with follow up design. Pengukuran kesejahteraan subjektif dilakukan dengan menggunakan skala SWLS dan PANAS yang telah diapatasi ke versi Indonesia. Pelatihan Kebersyukuran diberikan kepada individu yang terdiagnosa penyakit jantung pada usia produktif, yaitu 20-45 tahun $(n=5)$. Subjek mengikuti Pelatihan Kebersyukuran sebanyak 2 kali pertemuan melalui daring. Analisis yang digunakan pada penelitian ini, yaitu Uji Friedman yang menunjukkan hasil signifikan $\left(\chi_{\mathrm{r}^{2}}=8,4 ; \mathrm{p}<0,05\right)$. Hasil tersebut menunjukkan bahwa Pelatihan Kebersyukuran pada penelitian ini terbukti dapat meningkatkan kesejahteraan subjektif pada penderita penyakit jantung.
\end{abstract}

Kata kunci: Kesejahteraan Subjektif; Pelatihan Kebersyukuran; Penderita Penyakit Jantung

Jantung merupakan organ yang sangat penting bagi tubuh manusia. Hal tersebut menjadi sangat penting untuk menjaga kesehatan jantung agar dapat berfungsi dengan maksimal. Namun, beberapa orang sudah terlanjur terdiagnosa penyakit jantung sehingga membutuhkan 
perawatan secara intensif untuk memperpanjang angka harapan hidup pasien penyakit jantung (PERKI, 2019). Menurut WHO (2015), penyakit jantung merupakan penyakit tidak menular yang menjadi salah satu penyakit penyebab kematian tertinggi di dunia. Setiap tahunnya lebih dari 36 juta orang meninggal karena penyakit tidak menular, diantaranya disebabkan oleh penyakit jantung (WHO, 2015). WHO (2015) menambahkan bahwa lebih dari 9 juta kematian akibat penyakit jantung terjadi sebelum usia 60 tahun.

Informasi terakhir yang diperoleh dari hasil Riskesdas tahun 2018 menunjukkan bahwa di Indonesia terjadi peningkatan penyakit jantung di setiap tahunnya. Peningkatan tersebut terjadi baik itu pada laki-laki (1,3\%) maupun perempuan (1,6\%) (Kemkes RI, 2018). Berdasarkan data Riskesdas tahun 2018, kurang lebih terdapat 15 dari 1000 orang, atau sekitar 2.784 .064 jiwa di Indonesia menderita penyakit jantung (PERKI, 2019).

Saat ini, penyakit jantung tidak hanya diderita oleh kalangan usia lanjut, tetapi juga sudah banyak ditemukan pada usia muda, yang tergolong ke dalam usia produktif (15-45 tahun). Data prevalensi sebesar 39\% penyakit jantung diderita oleh individu yang berusia $<44$ tahun, dan sebanyak 22\% dari penderita jantung usia muda tersebut ada di kisaran usia 15-35 tahun (Kemkes RI, 2018). Terjadinya pergeseran usia penderita penyakit jantung disebabkan karena adanya perubahan pola hidup kurang sehat, seperti mengonsumsi makanan kolesterol tinggi, konsumsi alkohol, merokok, jarang berolahraga, dan sebagainya (Kemkes RI, 2017). Dengan demikian, perlu dilakukan pencegahan primer dan penanganan pada individu yang terlanjur terdiagnosa (Stewart, Manmathan, \& Wilkinson, 2017)

Setiap individu mengharapkan hidupnya bahagia dan merasa puas dengan kehidupannya, begitupun dengan pasien penyakit jantung. Namun, setelah didiagnosa penyakit jantung, individu tersebut menghadapi situasi baru yang bersifat menahun sehingga secara tidak langsung akan berdampak pada kondisi psikologis yang terkait kebahagiaan dan kepuasan hidup (Harrington, 2013; Baumgardner \& Crothers, 2014). Kebahagiaan merupakan konsep dasar dari kesejahteraan subjektif, di mana hal tersebut tercapai apabila kondisi yang dialami individu bersangkutan dapat melampaui standar kehidupan yang telah ditetapkannya (Diener, 1984). Berdasarkan penelitian yang dilakukan oleh Tina \& Utami (2016) menemukan bahwa pasien penyakit jantung sebagian besar mengalami kondisi kesejahteraan subjektif pada 
tingkat sedang. Hal tersebut berarti bahwa pasien penyakit jantung merasa kurang puas terhadap kehidupannya, dan sering merasakan afek negatif daripada afek positif.

Diener (2000) menjelaskan bahwa kesejahteraan subjektif merupakan evaluasi penilaian individu secara keseluruhan terhadap kehidupannya yang tidak terlepas dari penilaian kognitif terkait kepuasan hidup, dan juga penilaian afeksi terhadap pengalaman yang dialaminya. Lebih lanjut lagi dijelaskan bahwa kesejahteraan subjektif sebagai evaluasi umum dari kualitas hidup seseorang yang terdiri atas tiga komponen utama, yaitu (1) penilaian kognitif tentang bagaimana kehidupannya (kepuasan hidup); (2) pengalaman emosi positif yang tinggi (kesenangan, kepuasan hati, rasa bangga, kasih sayang, kebahagiaan, dan perasaan sangat gembira); (3) pengalaman emosi negatif yang rendah (perasaan bersalah dan malu, kesedihan, kecemasan dan marah, stress, depresi, iri hati) (Diener, 2000). Kesejahteraan subjektif yang tinggi akan tergambar dari kepuasan hidup yang tinggi, afeksi positif lebih tinggi daripada afeksi negatif dari pengalaman yang dialami.

Menurut Sarafino \& Smith (2014) bahwa kondisi sakit maupun sehat merupakan interaksi antara 3 aspek, yaitu biologis, psikologis, dan sosial. Dengan kata lain, interaksi ketiga aspek tersebut menggambarkan bahwa suatu kondisi sakit tidak hanya dipengaruhi dan berdampak pada fisik saja, tetapi juga mempengaruhi dan berdampak pada kondisi psikologis dan sosial individu tersebut. Penyakit jantung berdampak terhadap berbagai aspek kehidupan penderitanya. Secara fisik penderita akan merasakan sesak, mudah lelah, mengalami gangguan seksual, serta nyeri pada dada (Rosidawati, Ibrahim, \& Nuraeni, 2015). Secara psikologis mengalami perasaan cemas dan depresi (Davidson, et al., 2013). Lebih lanjut lagi ditemukan bahwa pasien penyakit jantung cenderung mengalami kecemasan, depresi, kemarahan, dan keputusasaan (Sarafino \& Smith, 2014).

Harrington (2013) menjelaskan bahwa individu yang terdiagnosa penyakit jantung pada awalnya akan mengalami kecemasan, ketakutan akan kematian, rasa ketidakberdayaan. Denollet (2008) menambahkan bahwa pasien penyakit jantung akan mengalami kecemasan, marah, gejala depresi, kekhawatiran dan stres, kelelahan yang berlebihan, serta adanya keputusasaan dan menurunnya kepuasaan terhadap hidupnya. Hal tersebut menunjukkan bahwa individu yang menderita penyakit jantung akan mengalami lebih banyak afek negatif 
daripada afek positif. Tingginya afek negatif daripada afek positif, dan kepuasan hidup yang menurun merupakan kondisi yang menunjukkan kesejahteraan subjektif yang rendah.

Adanya pengobatan yang berlangsung lama dan teratur, kekambuhan yang tidak dapat diprediksi, penyakit yang jangka panjang dan potensi kematian secara mendadak, pembatasan gaya hidup, biaya yang dibutuhkan dalam jumlah besar, serta menjadi beban bagi keluarga menyebabkan munculnya beban psikologis bagi pasien penyakit jantung. Beban psikologis yang dialami selama pasien didiagnosa penyakit jantung menyebabkan terjadinya risiko rendahnya kesejahteraan subjektif yang ditandai dengan kepuasan hidupnya yang mengalami penurunan, afeksi negatif yang lebih dominan daripada afeksi positif seperti ketakutan, kekhawatiran, rasa bersalah, tertekan, mudah marah. Dengan kondisi tersebut, diperlukan intervensi untuk meningkatkan kesejahteraan subjektif pada pasien penyakit jantung (Harrington, 2013).

Pressman \& Cohen (2005) mengungkapkan bahwa afek positif berkaitan erat dengan kesehatan fisik dan umur panjang, serta dapat memprediksi tingkat kemampuan individu untuk bertahan terhadap penyakit yang dideritanya. Terdapat beberapa jenis intervensi yang telah terbukti dapat meningkatkan kesejahteraan subjektif, antara lain pelatihan kebersyukuran (Dewanto \& Retnowati, 2015); terapi pemaafan (Tyas \& Subandi, 2013); pelatihan regulasi emosi (Putri, Uyun, \& Sulistyarini, 2017); dan mindfulness (Larashati \& Hasanat, 2019). Intervensi yang dapat dilakukan untuk meningkatkan kesejahteraan subjektif yaitu dengan meningkatkan afek positif dan kepuasan hidup, serta menurunkan afek negatif. Melalui pelatihan kebersyukuran, maka individu dapat meningkatkan afek positif dan fleksibilitas dalam merespon, menurunkan reaktivitas pikiran dan emosi, dan menurunkan afek negatif (Emmons \& McCullough, 2004).

Pemilihan intervensi Pelatihan Kebersyukuran untuk meningkatkan kesejahteraan subjektif pada pasien penyakit jantung karena pengungkapan rasa syukur merupakan salah satu kekuatan dasar yang dimiliki setiap individu yang dapat menigkatkan afeksi positif dan kepuasan hidup (Watkins, 2014). Selain itu, dengan adanya kebersyukuran, maka individu dengan penyakit jantung akan mensyukuri dan mengubah persepsi bahwa hal baik atau keberkahan juga akan diperoleh dari situasi yang tidak menyenangkan (Seligman, 2005). Pada 
penelitian ini diharapkan pasien penyakit jantung akan mampu menemukan hal yang menjadi keberkahan dengan penyakit kronis yang dialami melalui pelatihan kebersyukuran.

Watkins (2014) mendefinisikan kebersyukuran sebagai penghayatan individu yang muncul dari dalam diri terhadap hal baik yang terjadi dalam hidupnya, serta orang lain juga memberikan kontribusi atas terjadinya hal baik tersebut. Adanya rasa bersyukur dapat membuat individu memiliki pandangan yang lebih positif dan perspektif yang lebih luas mengenai kehidupan, yaitu memandang kehidupan sebagai suatu anugerah (Seligman \& Peterson, 2004).

Adapun yang dimaksud dengan pelatihan kebersyukuran yaitu serangkaian kegiatan yang dilakukan bertujuan untuk meningkatkan kemampuan individu dalam mensyukuri segala sesuatu yang terjadi pada kehidupannya, baik itu berupa ucapan maupun perbuatan (Emmons, 2007). McCullough \& Cohen (2008) menambahkan bahwa pelatihan kebersyukuran dapat memunculkan emosi yang menyenangkan, seperti munculnya kebahagiaan karena rasa syukur tersebut akan memberi dampak bagi diri sendiri dan orang lain. Fokus terhadap rasa syukur dapat membuat hidup lebih memuaskan, bermakna, dan produktif (Snyder \& Lopez, 2002). Melalui penelitian yang telah dilakukan oleh Emmons \& McCullough (2004), ditemukan bahwa rasa syukur dapat meningkatkan emosi positif dan menciptakan kebahagiaan. Pelatihan Kebersyukuran terdiri atas 3 aspek, yaitu sense of abundance, appreciation of simple pleaser, dan appreciation of others (Watkins, Woodward, Stone, \& Kolts, 2003). Aspek tersebut mencakup 4 tahapan yang dapat dilakukan melalui pelatihan kebersyukuran, berupa menghitung kembali berkah yang diperoleh, merefleksikan rasa syukur, mengekspresikan rasa syukur, dan menilai kembali berkah yang telah diperoleh (Watkins, 2014).

Oleh karena itu, pada penelitian ini diharapkan bahwa penderita penyakit jantung yang berisiko mengalami kondisi kesejahteraan subjektif rendah dapat ditingkatkan melalui Pelatihan Kebersyukuran, sehingga pengalaman afek positif dan kepuasaan hidup dapat meningkat, serta menurunkan pengalaman afek negatif yang dialami. Adapun hipotesis yang diajukan pada penelitian ini, yaitu tingkat kesejahteraan subjektif pasien penyakit jantung lebih tinggi setelah diberikan Pelatihan Kebersyukuran daripada sebelum diberikan pelatihan kebersyukuran. Berdasarkan uraian di atas, maka penelitian ini bertujuan untuk menguji 
efektivitas Pelatihan Kebersyukuran terhadap peningkatkan kesejahteraan subjektif pada penderita penyakit jantung.

\section{Metode}

\section{Variabel Penelitian}

Adapun definisi operasional variable pada penelitian ini sehingga memberikan Batasan terhadap variable adalah sebagai berikut: (a) Kesejahteraan subjektif (VT), yaitu evaluasi individu dalam memandang kehidupannya secara keseluruhan, yang terlihat dari penilaian secara kognitif tentang bagaimana kepuasan terhadap kehidupannya, memiliki pengalaman afek positif yang lebih tinggi, dan memiliki pengalaman afek negatif yang rendah. (b) Pelatihan Kebersyukuran (VB), yaitu serangkaian kegiatan pelatihan psikis yang tersusun secara sistematis dengan tujuan memberikan pengetahuan dan keterampilan bersyukur sebagai bentuk rasa terima kasih kepada Tuhan yang telah memberikan karunia atau nikmat.

\section{Subjek Penelitian}

Subjek dalam penelitian ini adalah pasien penyakit jantung dengan kriteria sebagai berikut: (a) berusia 20-45 tahun, (b) telah didiagnosa penyakit jantung oleh dokter, (c)mempunyai skor kesejahteraan subjektif dalam kategori rendah atau sedang, (d) mempunyai skor kebersyukuran dalam kategori rendah atau sedang, (e) mampu berbahasa Indonesia dengan baik secara lisan dan tulisan, (f) mampu dan bersedia untuk mengikuti proses intervensi secara keseluruhan. Berdasarkan skrining melalui penyebaran skala secara daring menggunakan google form yang telah diisi oleh 18 orang subjek, diperoleh hasil bahwa terdapat 8 subjek yang bersedia untuk mengikuti intervensi secara keseluruhan. Namun, hanya terdapat 5 subjek yang termasuk dalam kriteria yang telah ditentukan.

\section{Instrumen Penelitian}

Kesejahteraan subjektif diukur dengan menggunakan 2 subskala, yaitu skala SWLS (the Satisfaction with Life Scale) yang dikembangkan oleh Diener, Emmons, Larsen, \& Griffin (1985) untuk mengukur aspek kepuasan hidup secara global, yaitu penilaian atau evaluasi individu secara kognitif terhadap keseluruhan hidupnya. Subskala yang kedua, yaitu PANAS (Positive 
Affect and Negative Affect Scale) yang dikembangkan oleh Watson, Clark, \& Tellegen (1988) untuk menggambarkan perasaan subjek, baik itu perasaan positif maupun perasaan negatif. Kedua subskala tersebut diadaptasi ke dalam versi Bahasa Indonesia oleh Akhtar (2019), yang kemudian digunakan pada penelitian ini.

Setelah dilakukan adaptasi oleh Akhtar (2019), diperoleh hasil uji reliabilitas skala SWLS sebesar r=0,828; Afek positif pada skala PANAS sebesar r=0,861; dan Afek negatif pada skala PANAS sebesar $r=0,853$, yang berarti skala tersebut dapat dipercaya untuk mengukur kepuasan hidup, afek positif dan afek negatif di Indonesia. Kemudian, hasil uji validitas item SWLS berkisar antara 0,553-0,686; item afek positif berkisar antara 0,450-0,664; dan item afek negatif berkisar antara 0,413-0,699, yang berarti item-item pada skala SWLS dan PANAS yang telah diadaptasi memiliki fungsi yang baik dan dapat berperan untuk membedakan individu yang memiliki dan tidak memiliki konstruk yang diukur.

Pada penelitian ini digunakan juga skala kebersyukuran ketika skrining untuk mengetahui subjek penelitian yang memiliki skor kebersyukuran dalam kategori sedang atau rendah. Kebersyukuran dalam penelitian ini diukur dengan menggunakan skala bersyukur versi Indonesia yang dikembangkan oleh Listiyandini, Nathania, Syahniar, Sonia, \& Nadya (2015). Skala tersebut dikembangkan berdasarkan aspek kebersyukuran dari Watkins, Woodward, Stone, \& Kolts (2003). Hasil uji reliabilitas skala bersyukur versi Indonesia ini sebesar $r=0,889$, yang berarti skala tersebut dapat dipercaya untuk mengukur kebersyukuran individu di Indonesia. Kemudian, hasil uji validitas item berkisar antara 0,32-0,79, yang berarti item pada skala tersebut memiliki fungsi yang baik.

Pada penelitian ini dilakukan juga wawancara dengan metode semi terstruktur untuk menganalisis kondisi kesejahteraan subjektif pasien penyakit jantung sebelum dan setelah diberikan pelatihan kebersyukuran. Selain itu, dilakukan pula observasi dalam penelitian ini untuk melihat proses, sikap, dan perilaku selama proses pelatihan kebersyukuran. Observasi dalam penelitian ini manggunakan metode pencatatan skala numeris dan deskriptif. 


\section{Rancangan Penelitian}

Penelitian ini merupakan penelitian rancangan eksperimen kuasi dengan desain eksperimen one group pretest-posttest with follow up design. Penelitian ini hanya menggunakan satu kelompok, yaitu kelompok eksperimen karena terbatasnya partisipan penelitian yang dapat mengikuti seluruh rangkaian intervensi. Kelompok subjek penelitian tersebut akan diberikan pengukuran kesejahteraan subjektif sebelum diberikan intervensi, dan pengukuran yang sama setelah diberikan intervensi, kemudian akan dilakukan follow up seminggu setelah dilakukannya intervensi tersebut. Pemberian intervensi berupa Pelatihan Kebersyukuran yang dilakukan melalui daring (online).

\section{Intervensi Pelatihan Kebersyukuran}

Modul Pelatihan Kebersyukuran yang digunakan pada penelitian ini mengadaptasi dan memodifikasi modul yang telah dikembangkan oleh Mukhlis (2017). Penelitian ini memodifikasi bagian penugasan yang dikerjakan selama pelatihan agar sesuai dengan karakteristik subjek penelitian. Namun, untuk inti materi utama tidak mengalami perubahan secara drastis. Pelatihan Kebersyukuran ini diberikan kepada seluruh subjek yang berpartisipasi dalam penelitian.

Modul tersebut dikembangkan berdasarkan aspek kebersyukuran yang mengacu pada 4 hal yang dapat dilakukan untuk meningkatkan rasa syukur individu yang dikemukakan oleh Watkins (2014). Adapun aspek tersebut berupa langkah-langkah, yaitu (1) menghitung kembali nikmat yang telah diperoleh, (2) merefleksikan rasa syukur, (3) mengekspresikan rasa syukur, dan (4) menilai kembali rasa syukur yang telah diperoleh.

Pelatihan kebersyukuran ini dilaksanakan sebanyak 2 kali pertemuan, dengan 1 pertemuan di setiap minggu atau dapat dikatakan bahwa jeda antar pertemuan 5-7 hari, yang berlangsung selama 2 minggu berturut-turut. Adapun jeda antar pertemuan bertujuan agar memberikan kesempatan kepada subjek untuk mempraktikkan pengetahuan dan keterampilan yang telah diperoleh dari pertemuan sebelumnya. Setiap pertemuan berlangsung dengan durasi \pm 2 jam yang diberikan melalui daring (online). 


\section{Metode Analisis Data}

Metode analisis data yang digunakan dalam penelitian ini adalah analisis dengan Uji Friedman untuk membandingkan hasil pretest, posttest, dan follow up. Kemudian menggunakan analisis Wilcoxon Signed Rank-Test untuk membandingkan hasil pretest dan posttest, serta hasil posttest dan follow up. Analisis tersebut dilakukan melalui aplikasi SPSS versi 22. Analisis data dilengkapi dengan analisis deskriptif yang dilakukan dengan menganalisis data hasil observasi dan wawancara, serta penugasan yang dikerjakan subjek untuk mengetahui proses dan perkembangan yang dialami subjek selama intervensi.

\section{H a s i 1}

Penelitian ini menganalisis data hasil pretest, posttest dan follow up yang diperoleh dari pengisian skala kesejahteraan subjektif. Berikut merupakan skor kesejahteraan subjektif penderita penyakit jantung yang menjadi subjek penelitian, skor tersebut sebagai gambaran kesejahteraan subjektif pada saat sebelum dan setelah diberikan Pelatihan Kebersyukuran, serta pada saat follow up.

Tabel 1

Tabel Skor Kesejahteraan Subjektif Subjek Penelitian

\begin{tabular}{clcccc}
\hline Subjek & JK & Usia & Pretest (Kategori) & Posttest (Kategori) & Follow up (Kategori) \\
\hline RPH & P & 23 & 42,18 (Sedang) & 66,54 (Tinggi) & 67,28 (Tinggi) \\
AN & P & 27 & 48,97 (Sedang) & 66,78 (Tinggi) & 74,31 (Tinggi) \\
NS & P & 43 & 54,01 (Sedang) & 68,65 (Tinggi) & 61,36 (Tinggi) \\
IR & P & 37 & 41,84 (Sedang) & 63,61 (Tinggi) & 72,18 (Tinggi) \\
TN & P & 39 & 45,32 (Sedang) & 64,42 (Tinggi) & 64,87 (Tinggi) \\
\hline
\end{tabular}

Tabel 1 menunjukkan bahwa seluruh subjek penelitian memiliki skor kesejahteraan subjektif pada kategori sedang. Setelah diberikan intervensi berupa Pelatihan Kebersyukuran skor kesejahteraan subjektif mengalami peningkatan sehingga termasuk pada kategori tinggi. Demikian pula pada skor kesejahteraan subjektif yang diperoleh pada saat follow up tetap berada di kategori tinggi. Hal tersebut menunjukkan terdapat perbedaan kategori skor kesejahteraan subjektif pasien penyakit jantung antara sebelum dan setelah diberikan Pelatihan Kebersyukuran. Bahkan, pengaruh dari pelatihan tersebut masih dialami oleh subjek penelitian setelah seminggu dilaksakannya Pelatihan Kebersyukuran. 
Adapun data yang telah dijabarkan di atas, dapat dideksripsikan sebagai berikut:

Tabel 2

Tabel Deskriptif Skor Kesejahteraan Subjektif

\begin{tabular}{lccccc}
\hline & N & Skor minimal & Skor maksimal & M & SD \\
\hline Pretest & 5 & 41,84 & 54,01 & 46,46 & 5,10 \\
Posttest & 5 & 63,61 & 68,65 & 66,00 & 2,01 \\
Follow up & 5 & 61,36 & 74,31 & 68,00 & 5,28 \\
\hline
\end{tabular}

$\mathrm{M}=$ Mean, $\mathrm{SD}=$ Standar Deviasi

Berdasarkan tabel 2, terlihat bahwa hasil pengukuran kesejahteraan subjektif sebelum diberikan Pelatihan Kebersyukuran (pretest) memiliki skor minimal sebesar 41,84 dan skor maksimal sebesar 54,01 ( $M=46,46 ; S D=5,10)$. Hasil pengukuran kesejahteraan subjektif setelah diberikan Pelatihan Kebersyukuran (posttest) memiliki skor minimal sebesar 63,61 dan skor maksimal sebesar 68,65 $(\mathrm{M}=66,00 ; \mathrm{SD}=2,01)$. Sedangkan hasil pengukuran kesejahteraan subjektif seminggu setelah diberikan Pelatihan Kebersyukuran (follow up) memiliki skor minimal sebesar 61,36 dan skor maksimal sebesar 74,31 $(M=68,00 ; S D=5,28)$.

\section{Uji Hipotesis}

Pada penelitian ini digunakan Uji Friedman untuk menguji hipotesis bahwa terdapat perbedaan skor kesejahteraan subjektif subjek penelitian pada pretest, posttest, dan follow up. Hasil Uji Friedman menunjukkan hasil yang signifikan $\left(\chi_{r^{2}}=8,4 ; p=0,015\right)$. Hal ini menunjukkan bahwa terdapat perbedaan antara skor kesejahteraan subjektif antara pretest, posttest, dan follow up.

Penelitian ini juga menggunakan uji Wilcoxon Signed Rank Test untuk mengetahui perbedaan skor kesejahteraan subjektif antara sebelum dan setelah diberikan Pelatihan Kebersyukuran. Hasil analisis tersebut menunjukkan terdapat perbedaan yang signifikan $(Z=-$ 2,023; $p=0,043)$, berarti bahwa Pelatihan Kebersyukuran dapat meningkatkan kesejahteraan subjektif pasien penyakit jantung. Selain itu, dilakukan uji Wilcoxon Signed Rank Test untuk mengetahui perbedaan skor kesejahteraan subjektif antara setelah diberikan Pelatihan Kebersyukuran dan tindak lanjut setelah seminggu diberikan Pelatihan Kebersyukuran. Hasil analisis tersebut menunjukkan tidak terdapat perbedaan yang signifikan $(Z=-1,214 ; p=0,225)$, 
berarti bahwa setelah seminggu diberikan Pelatihan Kebersyukuran, kondisi kesejahteraan subjektif pasien penyakit jantung tetap konsisten berada pada kategori tinggi.

Pada penelitian ini juga dilakukan analisis tambahan pada aspek kesejahteraan subjektif. Analisis yang dilakukan pada setiap aspek tersebut untuk mengetahui aspek yang mengalami perubahan signifikan setelah diberikannya Pelatihan Kebersyukuran. Berdasarkan hasil analisis dengan Wilcoxon Signed Rank Test menunjukkan hasil bahwa skor kepuasan hidup antara sebelum dan setelah diberikan Pelatihan Kebersyukuran memperoleh hasil yang signifikan $(Z=$ -2,497; $p=0,006)$. Hasil analisis skor afek positif antara sebelum dan setelah diberikan Pelatihan Kebersyukuran memperoleh hasil yang signifikan $(Z=-2,312 ; p=0,01)$. Demikian juga dengan hasil analisis skor afek negatif antara sebelum dan setelah diberikan Pelatihan Kebersyukuran memperoleh hasil yang signifikan $(Z=-2,805 ; p=0,02)$.

Berdasarkan hasil analisis terhadap masing-masing aspek kesejahteraan subjektif, maka dapat disimpulkan bahwa terjadi perubahan yang signifikan pada ketiga aspek, yaitu aspek kepuasan hidup, aspek afek positif, dan aspek afek negatif pada saat sebelum dan setelah diberikan Pelatihan Kebersyukuran.

\section{Pembahasan}

Tujuan dari penelitian ini adalah untuk menguji efektivitas Pelatihan Kebersyukuran terhadap peningkatan kesejahteraan subjektif pada pasien penyakit jantung. Hasil penelitian ini menunjukkan bahwa terjadi perubahan skor kesejahteraan subjektif subjek penelitian pada saat sebelum dan setelah diberikan Pelatihan Kebersyukuran. Hal ini ditunjukkan dengan hasil analisis statistik antara skor kesejahteraan subjektif yang diperoleh ketika pretest, posttest, dan follow up dengan koefisien sebesar $\chi^{2}=8,4(p<0,05)$, yang berarti terdapat perbedaan skor pada ketiga kondisi tersebut. Selain itu, didukung dengan rata-rata skor kesejahteraan subjektif yang lebih tinggi setelah diberikan Pelatihan Kebersyukuran $(M=66,00)$ daripada sebelum diberikan Pelatihan Kebersyukuran $(\mathrm{M}=46,46)$. Hal ini juga sejalan dengan penelitian Bahrampour \& Yazdkhasti (2014) yang menemukan bahwa rasa syukur yang tinggi akan memberikan efek tidak langsung pada penurunan afek negatif seperti stres, cemas, dan depresi, serta sangat berpengaruh terhadap perubahan kepuasan hidup. 
Penelitian ini juga melakukan analisis antara skor kesejahteraan subjektif pada pretest dan posttest dengan koefisien sebesar $Z=-2,023(p<0,05)$, yang berarti terdapat perbedaan yang signifikan antara sebelum dan setelah diberikan Pelatihan Kebersyukuran. Selain itu dilakukan analisis antara skor kesejahteraan subjektif pada posttest dan follow up dengan koefisien sebesar $Z=-1,214(p>0,225)$, yang berarti tidak terdapat perbedaan yang signifikan antara setelah diberikan Pelatihan Kebersyukuran dan setelah seminggu diberikan pelatihan tersebut, menunjukkan hasil yang konsisten. Hasil yang telah dijabarkan sebelumnya menunjukkan bahwa Pelatihan Kebersyukuran dapat meningkatkan kesejahteraan subjektif pada penderita penyakit jantung. Dengan demikian, hipotesis yang diajukan pada penelitian ini diterima.

Hasil penelitian ini membuktikan bahwa Pelatihan Kebersyukuran efektif meningkatkan kesejahteraan subjektif. Temuan penelitian Dewanto \& Retnowati (2015) yang menemukan bahwa individu yang melatih diri untuk bersyukur memiliki kesejahteraan subjektif yang lebih tinggi dibandingkan dengan individu yang tidak melatih diri untuk bersyukur. Selain itu, penelitian ini juga didukung dengan penelitian yang dilakukan oleh Jans-Beken, Lataster, Peels, Lechner, \& Jacobs (2017) yang menjabarkan bahwa adanya rasa syukur merupakan sumber penting untuk mencapai kesejahteraan subjektif yang lebih baik. Apabila individu terus berada pada kondisi afek negatif yang lebih dominan, maka akan berdampak juga pada kualitas hidup yang dijalani (Nuraeni, Mirwanti, Anna, Prawesti, \& Emaliyawati, 2016).

Pelatihan Kebersyukuran memberikan pengaruh terhadap kesejahteraan subjektif subjek penelitian. Adanya peningkatan skor kesejahteraan subjektif pada subjek dalam penelitian ini dipengaruhi oleh keadaan di mana subjek penelitian mampu menemukan hikmah dibalik keadaan yang tidak menyenangkan sekalipun, dalam hal ini terdiagnosa sakit jantung. Emmons \& Shelton (2002) menyatakan bahwa seseorang yang bersyukur dengan cara mengenali pikiran atau pengalaman yang menyenangkan, maka akan memperoleh hikmah dan cara berpikir positif terhadap kehidupannya, serta akan memperkaya emosi positif. Peningkatan skor kesejahteraan subjektif tersebut juga dipengaruhi oleh subjek yang telah mampu mengekspresikan rasa syukur yang dirasakan terhadap siapa yang telah memberikan kebaikan, nikmat atau berkah dalam hidupnya. Menurut Watkins (2014) bahwa pelatihan kebersyukuran dengan cara mencari siapa saja sumber pemberi kebaikan, serta mampu 
mengungkapkan atau membalas kebaikan yang diperoleh, maka emosi positif akan meningkat. Berdasarkan penelitian yang dilakukan oleh Christanto, dkk (2017) menemukan bahwa dengan mengungkapkan rasa bersyukur baik itu secara tertulis maupun lisan dapat meningkatkan kesejahteraan subjektif individu.

Semakin sering subjek melatih kemampuan bersyukur, maka subjek akan semakin mampu mengambil hikmah dalam menghadapi permasalahan yang tidak sesuai harapan. Bersyukur merupakan suatu kebiasaan untuk fokus dan mengapresiasi aspek positif dalam hidup, sehingga bersyukur dapat dilakukan dengan latihan sederhana dalam kehidupan seharihari (Wood, Froh, \& Geraghty, 2010). Kemampuan bersyukur secara otomatis akan meningkatkan kepuasan terhadap hidupnya, lebih banyak merasakan afek positif dibandingkan afek negatif, seperti adanya perasaan optimis, harapan untuk menjalani hidup, semangat, dan tidak mudah merasa cemas serta takut. Dengan bersyukur, maka individu akan lebih tenang dan tidak panik ketika menghadapi suatu permasalahan (Makhdlori, 2007). Individu yang bersyukur dapat memberikan penghargaan dan kebermaknaan terhadap dirinya, serta mempengaruhi keadaan kesejahteraan subjektif individu bersangkutan (Sansone \& Sansone, 2010). Penelitian yang dilakukan oleh Rash, Matsuba, \& Prkachin (2011) membuktikan bahwa individu yang berada dalam kondisi bersyukur terhadap kehidupan yang dijalani, maka akan menunjukkan tingkat harga diri dan kepuasan hidup yang tinggi.

Emmons \& McCullough (2004) mengungkapkan bahwa seseorang yang bersyukur akan sering mengalami afek yang positif, seperti kebahagiaan, memiliki kepuasan dalam hidupnya, lebih banyak memiliki harapan, serta tidak mudah mengalami depresi, kecemasan, dan iri hati. Dengan demikian, hasil penelitian ini menunjukkan bahwa Pelatihan Kebersyukuran memiliki manfaat bagi individu dengan penyakit jantung untuk meningkatkan kesejahteraan subjektifnya yang terdiri dari meningkatnya kepuasan hidup, lebih banyak merasakan afek positif dan sedikit merasakan afek negatif. Sejalan dengan temuan Megawati, Lestari, \& Lestari (2019) bahwa Pelatihan Kebersyukuran mampu meningkatkan kesejahteraan subjektif yang bertahan dalam jangka waktu lama, baik itu pada aspek kognitif maupun afektif.

Peningkatan kesejahteraan subjektif pada subjek, dalam hal ini adalah penderita penyakit jantung tidak terlepas dari adanya perubahan pada masing-masing komponen atau 
aspek dari kesejahteraan subjektif itu sendiri. Masing-masing aspek, yaitu kepuasan hidup (Z= 2497, $p<0,05)$, afek positif $(Z=-2,312, p<0,05)$, dan afek negatif $(Z=-2,805, p<0,05)$ mengalami perubahan yang signifikan antara sebelum dan setelah diberikan Pelatihan Kebersyukuran. Hal tersebut menunjukkan bahwa Pelatihan Kebersyukuran dapat mempengaruhi aspek kepuasan hidup menjadi meningkat, afek positif juga mengalani peningkatan, dan afek negatif mengalami penurunan. Mengekspresikan rasa syukur menunjukkan bahwa terdapat peningkatan besar terhadap kesejahteraan emosional dan penurunan signifikan terhdap gejala depresi, cemas, dan stres (Seligman, 2005).

Beban psikologis yang dialami subjek penelitian yang merupakan penderita penyakit jantung, seperti adanya pengobatan jangka panjang dan teratur, kekambuhan yang tidak dapat diprediksi, penyakit yang diderita sejak usia muda dan bersifat kronis serta adanya potensi kematian mendadak, pembatasan gaya hidup dan aktivitas sehari-hari. Beban psikologis yang dirasakan subjek tersebut, tanpa sadar menyebabkan subjek mengalami penurunan kepuasan dalam hidupnya dan lebih dominan merasakan afek negatif, seperti merasa takut dan khawatir mengenai kehidupannya yang tidak akan lama lagi, merasa tertekan karena pada usia yang masih relatif muda harus menjalani pengobatan jangka panjang dan seumur hidup, kekhawatiran merawat anak di kemudian hari, merasa malu karena tidak seberuntung yang lain, merasa sensitif dan mudah marah saat menyikapi hal yang tidak sesuai keinginan. Hal tersebut mencerminkan subjek penelitian memiliki kesejahteraan subjektif yang relatif rendah. Kesejahteraan subjektif merupakan konsep yang mencakup pengalaman dengan tingginya afek positif (menyenangkan), rendahnya afek negatif (tidak menyenangkan), dan tingginya kepuasan hidup (Diener, Lucas, \& Oishi, 2005).

Namun, setelah memperoleh Pelatihan Kebersyukuran, masing-masing subjek menyampaikan perubahan yang dirasakan, seperti mengetahui cara mengungkapkan rasa syukur, menyadari berkah dan nikmat yang telah diperoleh sehingga tidak hanya berfokus pada sakit jantung yang dialami, serta mampu menemukan hikmah dari pengalaman yang tidak menyenangkan. Hal tersebut telah membuat masing-masing subjek merasa lebih puas menjalani kehidupannya. Memaknai kembali kejadian negatif yang terjadi dengan bersyukur kemudian menggantinya dengan penilaian yang positif, tidak hanya efektif untuk 
meningkatkan kebahagiaan tetapi juga kepuasan hidup (Watkins, 2014). Selain itu, afek yang dirasakan lebih positif, seperti lebih bersemangat dan aktif menjalani keseharian, lebih tertarik dan antusias dalam melakukan banyak hal, merasa bangga atas pencapaian yang diperoleh selama ini, serta merasa lebih kuat untuk melawan penyakit jantung yang diderita. Fokus terhadap rasa syukur dapat membuat hidup lebih memuaskan, bermakna, dan produktif (Snyder \& Lopez, 2002). Kebersyukuran juga akan mempengaruhi individu dalam memandang kehidupannya sehingga lebih sejahtera (Watkins \& McCurrach, 2016)

Proses pemberian Pelatihan Kebersyukuran juga melibatkan proses terapeutik dalam kelompok. Adapun proses terapeutik yang terjadi selama berlangsungnya Pelatihan Kebersyukuran, yaitu membangun kepercayaan, sarana katarsis, keterbukaan, munculnya harapan baru, terjadinya umpan balik dalam kelompok, saling peduli, kebersamaan dan adanya penerimaan, berkomitmen untuk berubah jadi lebih baik, kohesivitas, dan penyampaian informasi. Yalom \& Leszcz (2005) menyebutkan beberapa faktor yang menimbulkan terjadinya terapeutik, yaitu memunculkan harapan, universal, memberi informasi, alturisme, komitmen, penerimaan, umpan balik, katarsis, pembelajaran interpersonal, kohesivitas kelompok, dan eksistensi. Berlangsungnya proses tersebut dalam kelompok, membuat Pelatihan Kebersyukuran berjalan sesuai dengan rencana, lebih kondusif dan dapat memberikan pengaruh positif bagi subjek penelitian.

Seluruh subjek penelitian mengikuti proses Pelatihan Kebersyukuran dari awal hingga berakhirnya pelatihan tersebut. Hal tersebut merupakan salah satu faktor keberhasilan fasilitator sebagai pemimpin kelompok yang dapat mempertahankan kelompok tersebut. Selain itu, terjalinnya hubungan yang baik antara fasilitator dan subjek penelitian, sehingga memberikan perubahan yang baik pula pada subjek. Pemimpin pada suatu kelompok bertugas untuk membuat dan mempertahankan kelompok (Yalom \& Leszcz, 2005; Corey \& Corey, 2014)). Subjek penelitian seluruhnya berjenis kelamin perempuan, begitupun dengan peneliti, observer, dan fasilitator sehingga seluruh subjek terlihat merasa nyaman dan terbuka selama proses pelatihan kebersyukuran, serta tidak segan untuk berbicara sambil menangis dan menceritakan pengalaman tidak menyenangkan yang dialami. Menurut Johnson \& Caldwell 
(2010), adanya kesamaan jenis kelamin dalam kelompok dapat meningkatkan kepuasan klien dalam proses terapeutik.

Masing-masing subjek penelitian memberikan evaluasi yang sangat baik terhadap cara penyajian dan kesesuian materi pelatihan, sistematika dan alur pelatihan, serta cara fasilitator saat memberikan pelatihan. Namun, perlu dievaluasi terkait pengelolaan waktu pelatihan yang agak terlambat, hal tersebut dikarenakan adanya gangguan koneksi internet pada beberapa subjek ketika akan memulai pelatihan. Evaluasi pada pelaksanaan pelatihan ini berupa memberikan pilihan pada dua kondisi yang tersedia, kemudian diperkuat dengan hasil observasi dari observer yang menunjukkan bahwa subjek tampak mengikuti instruksi dengan baik, dan diperkuat pula dengan hasil wawancara kepada subjek bahwa terdapat perubahan antara sebelum dan setelah diberikan Pelatihan Kebersyukuran. Adanya data pendukung tersebut menghindari terjadinya respon yang pura-pura baik (faking good), sehingga tetap menghasilkan evaluasi yang objektif.

Kelemahan penelitian ini terletak pada desain penelitian yang tidak menggunakan kelompok kontrol sebagai pembanding karena keterbatasan subjek yang bersedia mengikuti rangkaian proses intervensi secara daring (online). Diharapkan bagi peneliti selanjutnya menggunakan kelompok kontrol, sehingga hasil penelitian yang diperoleh tidak hanya sebatas membandingkan antara sebelum dan setelah diberikan Pelatihan Kebersyukuran, tetapi juga ada pembanding dengan kelompok yang tidak mendapatkan perlakuan intervensi. Apabila terdapat kelompok pembanding, maka akan mengetahui besar pengaruh perubahan dari intervensi yang diberikan (Corder \& Foreman, 2014).

Penelitian ini menunjukkan hasil bahwa Pelatihan Kebersyukuran dapat meningkatkan kesejahteraan subjektif pasien penyakit jantung meskipun dilaksanakan secara daring (online), mulai proses pengumpulan data sampai pemberian intervensi yang dilakukan melalui telepon, pesan aplikasi whatsapp, dan video konferensi. Meskipun demikian, terdapat beberapa kekurangan pada pelaksanaan penelitian secara daring ini, seperti data observasi yang diperoleh terbatas, adanya gangguan teknis pada koneksi internet, serta kontrol yang terbatas pada penugasan yang dikerjakan subjek selama pelatihan. 
Berdasarkan uraian di atas, dapat disimpulkan bahwa Pelatihan Kebersyukuran dapat meningkatkan kesejahteraan subjektif pada pasien penyakit jantung. Hal tersebut terlihat dari meningkatnya skor kesejahteraan subjektif antara sebelum diberikan Pelatihan Kebersyukuran dan setelah diberikan Pelatihan Kebersyukuran. Selain itu, terjadi perubahan pada masingmasing aspek kesejahteraan subjektif subjek setelah mendapatkan Pelatihan Kebersyukuran, yaitu terjadi peningkatan terhadap kepuasan hidupnya, lebih sering merasakan afek positif dibandingkan afek negatif.

\section{Kesimpulan}

Berdasarkan hasil analisis data penelitian dan pembahasan, maka dapat disimpulkan bahwa terdapat perbedaan tingkat kesejahteraan subjektif pada pasien penyakit jantung di usia produktif antara sebelum dan setelah diberikan intervensi Pelatihan Kebersyukuran. Kesejahteraan subjektif pasien penyakit jantung lebih tinggi setelah mendapatkan Pelatihan Kebersyukuran daripada sebelum diberikan pelatihan. Hal tersebut menunjukkan bahwa Pelatihan Kebersyukuran dapat meningkatkan kesejahteraan subjektif pasien penyakit jantung usia produktif. Dengan demikian, hipotesis penelitian ini dapat diterima.

Tujuan utama dari penelitian ini yaitu melalui Pelatihan Kebersyukuran, pasien penyakit jantung mampu menemukan hikmah dalam kondisi yang tidak menyenangkan dan tetap mampu mensyukuri apapun yang terjadi pada dirinya meskipun terdiagnosa penyakit jantung. Oleh karena itu, adanya rasa syukur dapat meningkatkan kepuasan hidup dan afeksi positif, serta mampu menurunkan afeksi negatif yang dirasakan pasien penyakit jantung sehingga menunjukkan kesejahteraan subjektif yang tinggi.

\section{Saran}

Subjek penelitian diharapkan dapat mengaplikasikan keterampilan bersyukur yang diperoleh selama pelatihan, serta terus berlatih dalam kehidupan sehari-hari untuk meningkatkan kemampuan bersyukur tersebut sehingga dapat menemukan hikmah dari setiap kondisi yang dialami, bahkan yang tidak menyenangkan sekalipun, yang akan berdampak pada peningkatan kesejahteraan subjektif individu bersangkutan. 
Pelatihan Kebersyukuran dalam penelitian ini terbukti dapat meningkatkan kesejahteraan subjektif bagi subjek penelitian, sehingga intervensi ini dapat menjadi salah satu alternatif intervensi yang dapat diberikan untuk meningkatkan kesejahteraan subjektif pasien penyakit jantung, khususnya usia produktif. Selain itu, temuan ini tentu diharapkan menjadi acuan literatur mengenai peningkatan kesejahteraan subjektif pasien penyakit jantung melalui Pelatihan Kebersyukuran. Bagi peneliti selanjutnya diharapkan dapat mempertimbangkan mengenai teknis pelaksanaan Pelatihan Kebersyukuran baik itu secara tatap muka langsung (offline) ataupun daring (online).

\section{Referensi}

Akhtar, H. (2019). Evaluasi Properti Psikometris dan Perbandingan Model Pengukuran Konstruk Subjective Well Being. Jurnal Psikologi, 18(1), 29-40.

Azwar, S. (2012). Metode Penelitian. Yogyakarta: Pustaka Pelajar.

Bahrampour, M., \& Yazdkhasti, F. (2014). The Relationship Between Gratitude, Depression, Anxiety, Stres and Life Satisfaction: A path Analysis Model. Reef Resources Assessment and Management Technical Paper, 40(1).

Baumgardner, S., \& Crothers, M. (2014). Positive Psychology. United State of America: Pearson Prentice Hall.

Christanto, S.A., Brenda, D., Assisiansi, C., Pangestu, M.J., Sarita, I., \& Sulistiani, V. (2017). Gratitude Letter: An Effort to Increase Subjective Well-Being in College. Anima Indonesian Psychological Journal, 32(3), 158-168.

Corder, G. W., \& Foreman, D. I. (2014). Nonparametric Statistics for Non Statisticians: a Step by Step Approach. Jersey: John Wiley \& Sons, Inc.

Corey, M., \& Corey, G. (2014). Process and Practice Groups (9 $9^{\text {th }}$ ed). Belmont: Thomson Brooks/ Cole.

Creswell, J. W. (2017). Research Design: Pendekatan Metode Kualitatif, Kuantitatif, dan Campuran. Yogyakarta: Pustaka Pelajar.

Davidson, K., Bigger, J., Burg, M., Carney, R., Chaplin, W., \& Czajkowski, S. (2013). Centralized, Stepped, Patient Preference-Based Treatment for Patients with Post Acute Coronary Syndrome Depression. JAMA International Medicine, 173(11), 997-1003.

Denollet, J. (2008). Personality and Coronary Heart Disease: the Type-d scale- 16 (dS-16). The Society of Behavioral Medicine, 20(3), 209-215.

Dewanto, W., \& Retnowati, S. (2015). Intervensi Kebersyukuran dan Kesejahteraan Subjektif Penyandang Disabilitas Fisik. Gadjah Mada Journal of Professional Psychology, 1(1), 33-47.

Diener, E. (1984). Subjective Well Being. Psychological Bulletin, 95(3), 542-575.

Diener, E. (2000). Subjective Well Being: The Science of Happiness and a Proposal for a National Index. American Psychologist, 34-43. 
Diener, E., Emmons, R., Larsen, R., \& Griffin, S. (1985). The Satisfaction with Life Scale. Journal of Personality Assessment, 49, 71-75.

Diener, E., Lucas, R., \& Oishi, S. (2005). Subjective Well Being: The Science of Happiness and Life Satisfaction. Psychology, 5(6).

Emmons, R., \& McCullough, M. (2004). The Psychology of Gratitude . New York: Oxford University Press, Inc.

Emmons, R., \& Shelton, C. (2002). Gratitude and the Science of Positive Psychology. New York: Oxford University Press.

Harrington, R. (2013). Stress, Health, and Well-Being: Thriving in the 21st Century. Belmont, CA: Wadsworht, Cengage.

Jans-Beken, L., Lataster, J., Peels, D., Lechner, L., \& Jacobs, N. (2017). Gratitude, Psychopathology and Subjective Well Being: Result from a 7.5-Month Prospective General Populastion Study. J Happiness Stud, 1-17.

Johnson, L.A., \& Caldwell, B.E. (2010). Race, Gender, and Therapist Confidence: Effects on Satisfaction with Therapeutic Relationship in MFT. Journal of Family Therapy, 39, 307-324.

Kemkes RI. (2014). Pusat Data dan Informasi: Situasi Kesehatan Jantung. Retrieved Februari 18, 2020, from Kementerian Kesehatan Republik Indonesia: htttp://www.kemkes.go.id

Kemkes RI. (2017, Juli 29). Penyakit Jantung Penyebab Kematian Tertiggi, Kemenkes Ingatkan CERDIK Penyakit. Retrieved 02 18, 2020, from Kementerian Kesehatan Republik Indonesia: http://www.kemkes.go.id

Kemkes RI. (2018). Riset Kesehatan Dasar 2018. Retrieved Februari 27, 2020, from Kementerian Kesehatan Republik Indonesia: http://www.depkes.go.id

Larashati, M. A., \& Hasanat, N. U. (2019). Program Mindfulness untuk Meningkatkan Kesejahteraan Subjektif Individu dengan Penyakit Jantung Koroner. Gadjah Mada Journal of Psychology, 1-10.

Listiyandini, R. A., Nathania, A., Syahniar, D., Sonia, L., \& Nadya, R. (2015). Mengukur Rasa Syukur: Pengembangan Model Awal Skala Bersyukur Versi Indonesia. Jurnal Psikologi Ulayat, 2(2), 473-496.

Makhdlori, M. (2007). Bersyukurlah maka Engkau akan Kaya. Yogyakarta: Diva Press.

Megawati, P., Lestari, S., \& Lestari, R. (2019). Gratitude training to Improve Subjective WellBeing among Adolescents Living in Orphanages. Humanitas Indonesian Psychological Journal, 16(1), 13-22.

Mukhlis, H. (2017). Pelatihan Kebersyukuran: Sebuah Upaya untuk Menurunkan Kecemasan Menghadapi Ujian Nasional pada Siswa SMA. Jurnal Psikologi, 1-10.

Nuraeni, A., \& Mirwanti, R. (2017). Hubungan Cemas dan Depresi pada Pasien dengan Penyakit Jantung Koroner (PJK). Medisains: Jurnal Ilmiah Ilmu-Ilmu Kesehatan, 15(1), 1016.

Nuraeni, A., Mirwanti, R., Anna, A., Prawesti, A., \& Emaliyawati, E. (2016). Faktor yang Memengaruhi Kualitas Hidup Pasien dengan Penyakit Jantung Koroner. Medisains: Jurnal Ilmiah Ilmu-Ilmu Kesehatan, 4(2), 107-116.

PERKI. (2019). Panduan Pelayanan External Counterpulation untuk Pasien dengan Penyakit Kardiovaskular. Jakarta: Indonesia Heart Association. 
Pressman, S., \& Cohen, S. (2005). Does Positive Affect Influence Health? Psychological Bulletin, 131, 925-971.

Rahmanita, A., Uyun, Q., \& Sulistyarini, R. I. (2016). Efektivitas Pelatihan Kebersyukuran untuk Meningkatkan Kesejahteraan Subjektif pada Pasien Hipertensi. Jurnal Intervensi Psikologi, 8(2), 165-184.

Rash, J.A., Matsuba, M.K., \& Prkachin, K.M. (2011). Gratitude and Well-Being: Who Benefits the Most from a Gratitude Intervention?. Applied Psychology: Health and Well Being, 3(3), 350369.

Putri, D. W., Uyun, Q., \& Sulistyarini, R. I. (2017). Pelatihan Regulasi Emosi untuk Meningkatkan Kesejahteraan Subjektif Orang dengan Hipertensi Esesnsial. Philantrophy Journal of Psychology, 1(1), 1-16.

Rosidawati, I., Ibrahim, K., \& Nuraeni, A. (2015). Kualitas Hidup Pasien Pasca Bedah Pintas Arteri Koroner di RSUP Dr. Hasan Sadikin Bandung. Journal Undip.

Sarafino, E., \& Smith, T. (2014). Health psychology: Biopsychosocial interactions. New York: John Wiley \& Son.

Sansone, R.A., \& Sansone, L.A. (2010). Gratitude and Well Being: The Benefits of Appreciation. Psychiatry (Edgemont), 7(11), 18-22.

Seligman, \& Peterson. (2004). Character, Strengh, and Virrues: A Handbook \& Classification. New York: Oxford University Press.

Seligman, M. E. (2005). Authentic Happiness: Using the New Positive Psychology to Realize Your Potential for Lasting Fulfillment. New York: Free Press.

Snyder, C., \& Lopez, S. (2002). Handbook of Positive Psychology. New York: Oxford University Press Inc.

Stewart, J., Manmathan, G., \& Wilkinson, P. (2017). Primary Prevention of Cardiovascular Disease: A Review of Contemporary Guidance and Literature. Journal of the Royal Society of Medicine Cardiovascular Disease(6), 1-9.

Sugiyono. (2017). Metode Penelitian Kuantitatif dan Kualitatif. Bandung: Alfabeta.

Tina, F. A., \& Utami, M. S. (2016). Religiusitas dan Kesejahteraan Subjektif pada Pasien Jantung Koroner. Gadjah Mada Journal of Psychology, 2(3), 162-171.

Tyas, M. P., \& Subandi. (2013). Terapi Pemaafan untuk Meningkatkan Kesejahteraan Subjektif Istri yang Berkonflik dengan Suami. Gadjah Mada Journal of Psychology, 1-10.

Utami, M. (2012). Religiusitas, Koping Religius, dan Kesejahteraan Subjektif. Jurnal Psikologi UGM, 39(1), 46-66.

Watkins, P. (2014). Gratitude and the Good Life: Toward a Psychology of Appreciation. New York: Springer.

Watkins, P., \& McCurrach, D. (2016). Exploring How Gratitude Trains Cognitive Processes Important to Well Being. Dalam David Carr (ed.) Perspective on Gratitude: An Interdisciplinary Approach. Amerika Serikat: Routledge.

Watkins, P., Woodward, K., Stone, T., \& Kolts, R. (2003). Gratitude and Happiness: Development of Measure Gratitude, and Relationship with Subjective Well Being. Social Behavior and Personality, 31(5), 431-452. 
Watson, D., Clark, L., \& Tellegen, A. (1988). Develompment and Validation of Brief Measures of Positive and Negative Affect: the PANAS scale. Journal of Personality and Social Psychology, 54(6), 1063.

WHO. (2015). Global Health Observatory (GHO). Retrieved Februari 18, 2020, from World Health Organization: htttp://who.int/gho/en/

Wood, A.M., Froh, J.J., \& Geraghty, A.W.A. (2010). Gratitude and Well Being: A Review and Theoretical Integration. Clinical Psychology Review, 30, 890-905.

Yalom, I., \& Leszcz, M. (2005). The Theory and Practice of Group Psychotherapy. New York: Basic Book, Inc Publisher.

\begin{tabular}{|l|l|l|l|l|}
\hline Submit & Review & Revisi & Diterima & Publis \\
\hline $16-08-2020$ & $05-10-2020$ sd 24-11-2020 & $24-11-2020$ & $24-11-2020$ & $27-1-2021$ \\
\hline
\end{tabular}

Ririn Nur Abdiah Bahar dan Moordiningsih

Universitas Mercu Buana Yogyakarta

Email : ririn.bahar21@gmail.com, moordiningsih@gmail.com 